\title{
Characteristics of Marine Blue-green Algae with Uric Acid as Nitrogen Source
}

\author{
By C. van BAALEN and J. E. MARLER \\ Institute of Marine Science, University of Texas, Port Aransas, Texas, U.S.A.
}

(Received 1 April 1963)

\section{SUMMARY}

Two types of growth response were found with several species of marine blue-green algae when uric acid was sole nitrogen source for growth. For some species the cell type produced was typical of a blue-green alga and the growth rate was like that with other nitrogen sources. The second cell type was atypical in pigmentation. The organisms had a low nitrogen and ash content and the growth rate was much impaired. The cell type seen with uric acid is considered to be probably a minimum for sustained growth of a blue-green alga. Lipid accumulation was not a characteristic of the nitrogen-deficient condition, rather a carbohydrate reserve of a polyglucose type is indicated. The growth data presented lead to the hypothesis that two different pathways for uric acid utilization may exist in blue-green algae, one probably a normal uricase type and the other a non-specific attack, possibly peroxidative.

\section{INTRODUCTION}

Uric acid has been reported to be utilized as sole nitrogen source for growth for several algae (Droop, 1955; Miller \& Fogg, 1958) and might also be an important organic nitrogen source in marine environments, particularly inshore areas. While examining the mechanism of uric acid utilization by several marine species of bluegreen algae we found two distinct growth responses. Some species of blue-green algae (e.g. Plectonema terebrans) gave a reasonable growth rate with uric acid as compared with nitrate, and had normal pigmentation. With other species (e.g. Agmenellum quadriplaticum) the growth rate with uric acid was much lower than with nitrate and the organisms looked as if they were suffering severe nitrogen limitation. We have examined the growth, elementary analysis and pigmentation of the cell type this produced, which appeared to represent an unrecognized, unusual and stable physiological state for a blue-green alga.

\section{METHODS}

The organisms used, except Phormidium persicinum, were those previously described by Van Baalen (1962). P. persicinum was obtained through the kindness of Dr L. Provasoli; we are indebted to Dr F. Drouet for identification of the cultures.

The growth medium used was ASP-2 (Provasoli, McLaughlin \& Droop, 1957) with the following modifications : phosphate increased 10 times and nitrate 20 times; initial $\mathrm{pH} \mathrm{8.2,} \mathrm{S-3} \mathrm{and} \mathrm{vitamin} \mathrm{B}_{12}$ added only when needed. For the uric acid medium nitrate was omitted and $\mathbf{0 . 0 3} \%$ uric acid, sterilized by filtration (Morton 
filter apparatus, Corning no. 33990) was added. The uric acid was dissolved by adding tris buffer and gentle heating. Allantoin and urea were also sterilized by filtration.

Growth experiments were done in large test tubes $(50 \times 400 \mathrm{~mm}$.) incubated in illuminated, thermostatically controlled water baths designed after Myers (1950). Continuous culture of Agmenellum quadriplaticum, strain PR-6, was done in apparatus like that described by Myers \& Clark (1944). Lighting was by one $13 \mathrm{~W}$. fluorescent lamp inserted in the centre of the chamber. Incubation was at $39^{\circ}$. The chamber was operated manually, one-half the volume of culture was drained and replaced with fresh medium every 2 days. Carbon dioxide was supplied as $1 \%(\mathrm{v} / \mathrm{v}) \mathrm{CO}_{2}$ in air. Other details of growth conditions are noted in Results.

Uric acid was determined by using a uricase preparation (Worthington Biochemicals, Freehold, New Jersey, U.S.A.). Dry-weight determinations were done by filtering the material on tared Millipore filters, rinsing with distilled water, and drying at $75^{\circ}$.

The chemical analyses of organisms were done by Huffman Microanalytical Lab., Wheatridge, Colorado, U.S.A.

The spectra of whole organisms were measured on a Carey 14 Spectrophotometer (Applied Physics Corp., Monrovia, California, U.S.A.) with Lucite plates ( $\frac{1}{8}$ in., no. 7328) inserted in the cuvettes after the method of Shibata (1958). We are indebted to Dr J. Myers for the use of the plates and the Carey Spectrophotometer. Other work on spectra was done with a Beckman DU Spectrophotometer.

Cell extracts were made using a Branson Sonifier, Model LS-75 (Stamford, Connecticut, U.S.A.). Glucose was identified and determined by using 'Glucostat' (Worthington Biochemicals) and by paper chromatography.

\section{RESULTS}

\section{Growth responses to uric acid}

Table 1 gives yields of nine marine isolates of blue-green algae grown with uric acid as sole nitrogen source. Two of the organisms, Plectonema terebrans strain Jamaica, Lyngbya Lagerheimii strain Mont, grew well and gave normal pigmentation. The other organisms which grew were bleached and showed a strong yellow coloration. The growth of strain Jamaica was followed further for comparison with Agmenellum quadriplaticum strain PR-6. Strain Jamaica grew with allantoin, urea or nitrate as nitrogen source with yields of organism of: $\mathrm{mg}$. dry weight/20 $\mathrm{ml}$. medium in $72 \mathrm{hr}$. of $8 \cdot 3,9.5$ and 6.9 , respectively. Strain PR-6 was selected for further study; the data following will deal with it.

\section{Growth of Agmenellum quadriplaticum strain PR-6}

Figure 1 presents the growth and uric acid utilization of Agmenellum quadriplaticum strain PR-6. The specific growth rate constant $k$ in $\log _{10}$ units/day with uric acid as sole nitrogen source was $0 \cdot 14$; with nitrate under the same conditions the value of $k$ was $2 \cdot 2$, and on urea $2 \cdot 4$. Strain PR-6 did not grow with allantoin, adenine, guanine, xanthine, hypoxanthine, uracil, 5-methyl-cytosine, cytosine or thymine as sole nitrogen source; nor when combined nitrogen was omitted from the medium. An uninoculated tube of uric acid medium prepared, incubated, and 
treated in the same way as a growth run showed no evidence of uric acid decomposition. Apart from a slight increase in size of organism no microscopic differences between uric acid-grown and nitrate-grown organisms of strain PR-6 were observed.

Table 1. The growth of certain blue-green algae with uric acid as sole nitrogen source

$$
\begin{array}{ccc}
\text { Organism (stock designation } & \begin{array}{c}
\text { Yield of organism } \\
\text { in parentheses) }
\end{array} & \begin{array}{c}
\text { medry weight } / 20 \mathrm{ml} . \\
\text { Unic acid }
\end{array} \\
\text { Un } 11 \text { days) } & \text { used (mg.) }
\end{array}
$$
Organism (stock designation in parentheses)
(mg. dry weight $/ 20 \mathrm{ml}$. Uric acid medium in 11 days) used (mg.)

Incubation at $39^{\circ}, 600 \mathrm{ft}$.-c., fluorescent

$\begin{array}{lrl}\text { Coccochloris elabens (A-1) } & 5 \cdot 9 & 1 \cdot 5 \\ \text { Microcoleus chthnoplastes (Ba-1)* } & 14 \cdot 4 & 3 \cdot 3 \\ \text { Anacystis marina (6) } & 4 \cdot 6 & 2 \cdot 2 \\ \text { Oscillatoria Williansii (Mev)* } & 20 \cdot 2 & 1 \cdot 8 \\ \text { Plectonema terebrans (Jamaica) } & 41 \cdot 2 & 6 \cdot 0 \\ \text { Agmenellum quadriplaticum (PR-6) } & 24 \cdot 0 & 6 \cdot 0\end{array}$

Incubation at $30^{\circ}, 400 \mathrm{ft} .-\mathrm{c}$, fluorescent

$\begin{array}{lrr}\text { Lyngbya lagerheimii (Mont) } & 22 \cdot 6 & 3 \cdot 8 \\ \text { Phormidium persicinum } & 0 \cdot 0 & 0 \cdot 0 \\ \text { Plectonema terebrans (Cal Sp31) } & 0 \cdot 0 & 0 \cdot 0\end{array}$

* Growth very gelatinous.

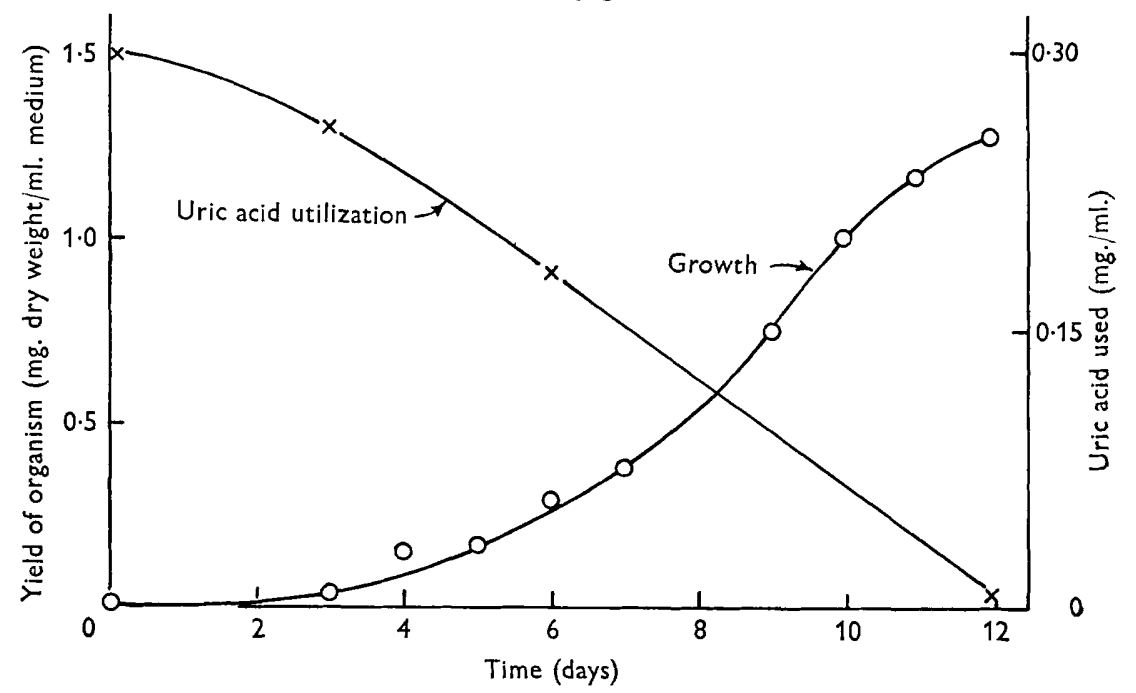

Fig. 1. Growth $(\bigcirc)$ and uric acid utilization $(\times)$ by Agmenellum quadriplaticum strain PR-6. Temperature $39^{\circ} ; 600 \mathrm{ft}$.-c., fluorescent light.

\section{Elementary analysis of Agmenellum quadriplaticum strain PR-6} grown on uric acid and nitrate

Table 2 presents the results of chemical analyses on samples of washed and dried uric acid-grown and nitrate-grown organisms of Agmenellum quadriplaticum strain PR-6. The R-value and percentage composition of protein, carbohydrate and lipid were calculated after the method of Spoehr \& Milner (1949). The heat of combustion and $\mathbf{R}$-value for uric acid-grown organisms were, as expected, low as compared to nitrate-grown PR-6 organisms and as compared to Spoehr \& Milner's values for 
Chlorella. A striking feature of the protein, carbohydrate, lipid calculation, even though admittedly an approximation, was the high carbohydrate value of the uric acid-grown organisms. The opposite effect was seen by Spoehr \& Milner, namely, with Chlorella pyrenoidosa (Emerson) low nitrogen produced a high lipid content.

Table 2. Cell analyses of Agmenellum quadriplaticum strain PR-6

\begin{tabular}{|c|c|c|c|c|}
\hline \multirow[b]{2}{*}{ Carbon (\%) } & \multicolumn{2}{|c|}{$\begin{array}{c}\text { Uric acid-grown } \\
\text { organisms }\end{array}$} & \multicolumn{2}{|c|}{$\begin{array}{c}\text { Nitrate-grown } \\
\text { organisms }\end{array}$} \\
\hline & $43 \cdot 58$ & $43 \cdot 20$ & $46 \cdot 64$ & $46 \cdot 25$ \\
\hline Hydrogen (\%) & $6 \cdot 40$ & $6 \cdot 54$ & $6 \cdot 58$ & $6 \cdot 49$ \\
\hline Residue $(\mathbf{C}-\mathbf{H})(\%)$ & $3 \cdot 6$ & $4 \cdot 4$ & $7 \cdot 6$ & $6 \cdot 4$ \\
\hline Nitrogen $(\%)$ & $2 \cdot 69$ & $2 \cdot 90$ & $9 \cdot 70$ & $9 \cdot 61$ \\
\hline R-Value & $32 \cdot 8$ & - & $\mathbf{3 7} \cdot \mathbf{3}$ & - \\
\hline Protein (\%) & 18 & - & 64 & - \\
\hline Carbohydrate $(\%)$ & 74 & 一 & 27 & - \\
\hline Lipid (\%) & 7 & - & 9 & - \\
\hline$\Delta \mathbf{H}_{\mathrm{c}}$ & $4.38 \mathrm{kcal} . / \mathrm{g}$ & - & $5.03 \mathrm{kcal} . / \mathrm{g}$. & - \\
\hline
\end{tabular}

A hot water extract of uric acid-grown PR-6 organisms gave no indication of a large soluble carbohydrate concentration. Upon hydrolysis of the residue from the hot water extract with $2 \mathrm{~N}-\mathrm{H}_{2} \mathrm{SO}_{4}$ for $6 \mathrm{hr}$. a strong positive test for glucose was found. Quantitative estimation showed that about $40 \%$ of the cell dry weight could be accounted for as glucose; no other sugars were detected. Evidently a polyglucose material is a main reserve product of uric acid-grown organisms. We have not further examined the nature of the polymer. It is clear, at least with strain PR-6 and perhaps it is a valid generalization for blue-green algae, that nitrogen deficiency does not predispose towards lipid accumulation. The same conclusion was tentatively reached by Fogg (1956) and Collyer \& Fogg (1955). Calculation from the cell yield of organism in mg. dry weight shown in Fig. 1 and from the nitrogen content by analysis in Table 2 indicates that uric acid-grown strain PR-6 organisms consume on the average only one-third of the nitrogen of uric acid.

\section{Pigment characteristics of Agmenellum quadriplaticum strain PR-6 on uric acid}

Figure 2 presents three types of measurements of the pigment characteristics of Agmenellum quadriplaticum strain PR-6 grown with uric acid. There was slight variation in the curves depending on whether the organisms were batch grown or harvested from the continuous culture chamber, due we believe to slight impurities in the uric acid which can be used as nitrogen sources. By using the calculations of Myers \& Kratz (1955) we find $0.29 \%$ chlorophyll, $0.48 \%$ phycocyanin, and $0.5 \%$ carotenoid, for the curves shown. There is some uncertainty about the reliability of the values for phycocyanin. We are not presently prepared to make the statement that uric acid-grown cells of PR-6 contain no phycocyanin. Other blue-green algae we have examined had still lower \% chlorophyll/mg. dry-weight values and even slighter indication of any phycocyanin. The data do reflect the fact that chlorophyll is more important for survival and sustained growth under suboptimal conditions. The carotenoid value is one-half the lowest value obtained by Myers \& Kratz (1955) with Anacystis nidulans. 


\section{Pigment recovery}

Figure 3 shows the results of a typical pigment recovery experiment, when washed uric acid-grown Agmenellum quadriplaticum strain PR-6 was supplied with ammonia, the required ions, and vitamin $\mathrm{B}_{12}$. When the organisms were suspended in $1 \cdot 8 \% \mathrm{NaCl}+0 \cdot 16 \mathrm{M}$-tris buffer $(\mathrm{pH} 8 \cdot 1)+1 \mathrm{mg}$. $\mathrm{NH}_{4} \mathrm{Cl} / \mathrm{ml}$. and incubated in the light, only a small increase of pigment was seen. By visual observation of pigment

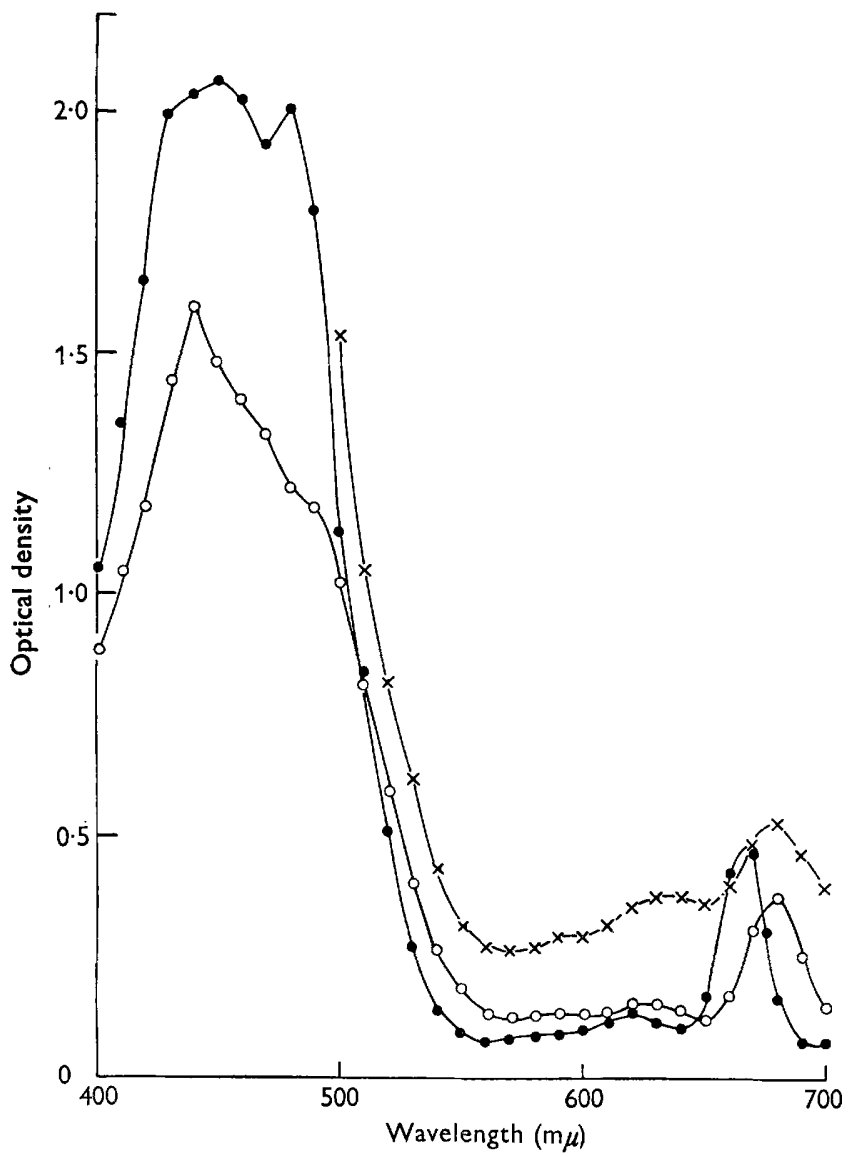

Fig. 2. Pigment curves for uric acid-grown Agmenellum quadriplaticum strain PR-6. Curves represent the extract of $2 \mathrm{mg}$. dry wt. organism $/ \mathrm{ml}$.; $1.0 \mathrm{~cm}$. light path. $\times$, opal glass: $O$, organism broken by Branson sonifier: $\bullet, 80 \%$ acetone. Cell source continuous culture chamber, population density at harvest, equivalent to $0.9 \mathrm{mg}$. dry wt. organism $/ \mathrm{ml}$.

recovery we found that, in addition to the above materials, the following ions were also essential, all added at the concentration as in medium ASP-2: $\mathrm{Mg}^{2+}, \mathrm{SO}_{4}{ }^{2-}$, FeEDTA, $\mathrm{K}^{+}, \mathrm{PO}_{4}{ }^{3-}$.

Pigment recovery did not take place when helium or air scrubbed with $\mathrm{KOH}$ was passed through the tubes. Recovery was normal with $1 \%(\mathrm{v} / \mathrm{v}) \mathrm{CO}_{2}$ in nitrogen.

In the first few hours a rapid uptake of ammonia occurred and very little pigment synthesis was evident until after about $7 \mathrm{hr}$. The $2-3 \mathrm{hr}$. pigment curve characteristically showed a slight decrease in the $600-700 \mathrm{~m} \mu$ region. 
The greatest degree of recovery can be seen in the phycocyanin area of the curve. The time course for pigment recovery could be varied $\pm 30 \%$ depending on the concentration of organisms and the light intensity used. It is of interest that, as shown in these recovery experiments and also in the cell analyses, uric acid-grown organisms in addition to nitrogen deficiency also had a mineral deficiency.

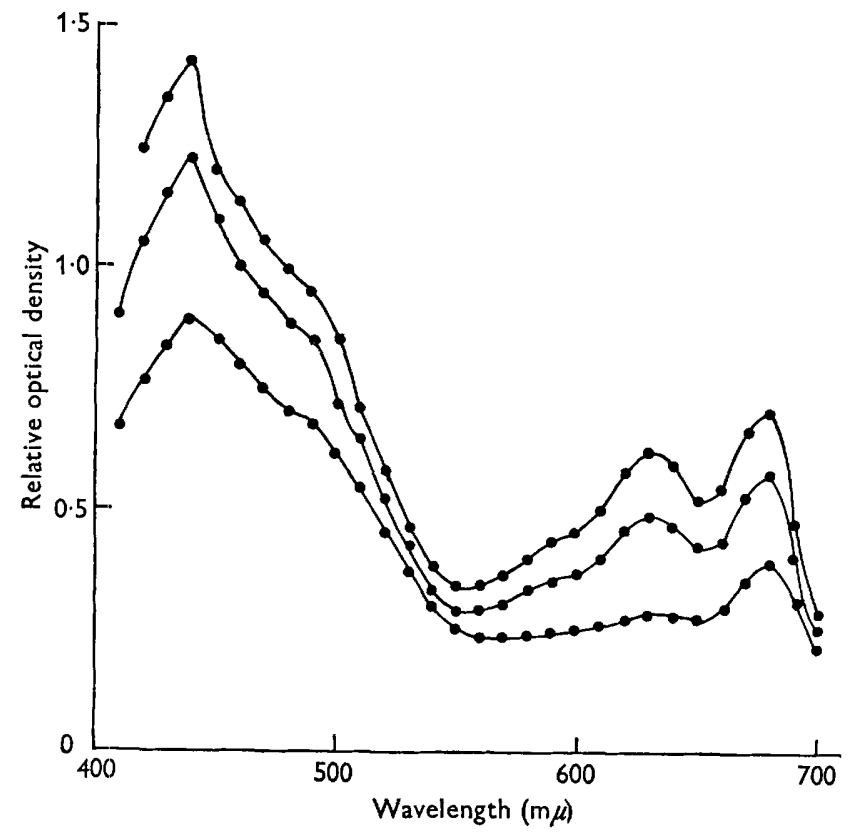

Fig. 3. Recovery curves, conditions: $33^{\circ}, 400 \mathrm{ft}$.-c. tungsten. Cells from continuous culture chamber, washed and suspended in recovery medium. Curves are for whole organisms taken with opal glass, Carey 14 Spectrophotometer, Agmenellum quadriplaticum strain PR-6. Lower curve 0 time, middle curve after $10 \mathrm{hr}$. incubation, upper curve after $13 \mathrm{hr}$. incubation.

\section{DISCUSSION}

The following points about the blue-green algal type seen here when uric acid is sole nitrogen source may be made. As quoted by Fritsch (1952) nitrogen chlorosis of blue-green algae in natural conditions is commonly seen, the implication being that growth is not occurring. The data presented here show that nitrogen deficiency results in a stable physiological state and that continued and reproducible growth can be maintained under these conditions experimentally and probably under natural conditions. It seems probable that uric acid-grown Agmenellum quadriplaticum strain PR-6 represents a minimum condition for growth in a blue-green alga. We do not consider that the low growth rate and extreme nitrogen deficiency manifested by strain PR-6 while growing on uric acid is directly related to uric acid but rather to the very limited ability of the organisms to degrade it to a useful nitrogen source. We have searched for other nitrogen sources that would produce a similar effect but have found none. The possibility that uric acid or a product derived from its breakdown is acting as an inhibitor of some stage in nitrogen assimilation seems remote. We have found no evidence that uric acid, allantoin, 
alloxanic acid, parabanic acid or oxonic acid (Brandenberger, 1954) affect strain PR-6 when nitrate is the nitrogen source.

A comparison of the growth data for Agmenellum quadriplaticum strain PR-6 and the Plectonema terebrans strain Jamaica growing on uric acid leads to the hypothesis that there are two different pathways for uric acid breakdown. We are tempted to ascribe to $\boldsymbol{P}$. terebrans strain Jamaica and to Lyngbya Lagerheimii strain Mont a normal uricase, uric acid $\rightarrow$ allantoin $\rightarrow$ urea system. For $A$. quadriplaticum strain PR-6 and organisms which behave similarly, a non-specific peroxidase activity is a possible explanation (Canellakis, Tuttle \& Cohen, 1954).

The work was supported by National Science Foundation (U.S.A.) Grant no. 19198.

\section{REFERENCES}

Brandenberger, H. (1954). The oxidation of uric acid to oxonic acid (allantoxanic acid) and its application in tracer studies of uric acid biosynthesis. Biochim. biophys. Acta, 15, 108.

Canellakis, E. S., Tuttle, A. L. \& Cohen, P. P. (1954). Comparative study of the endproducts of uric acid oxidation by peroxidases. J. biol. Chem. 213, 397.

Collyer, D. N. \& FogG, G. E. (1955). Studies on fat accumulation by algae. J. exp. Bot. 6, 256.

Droop, M. R. (1955). Some new supra-littoral protista. J. Mar. biol. Ass. U.K. 34, 233.

FoGG, G. E. (1956). The comparative physiology and biochemistry of the blue-green algae. Bact. Rev. 20, 148.

Fritsch, F. E. (1952). Structure and Reproduction of the Algae, 2, 782. Cambridge University Press.

Miller, J. D. A. \& FogG, G. E. (1958). Studies on the growth of Xanthophyceae in pure culture. II. The relations of Monodus subterrans to organic substances. Arch. Mikrobiol. 30, 1.

Myers, J. \& Clark, J. B. (1944). Culture conditions and the development of the photosynthetic mechanism. II. An apparatus for the continuous culture of Chlorella. J. gen. Physiol. 28, 103.

Myers, J. (1950). In The Culturing of Algae, p. 45. Yellow Springs, Ohio: Kettering Foundation.

Myers, J. \& Kratz, W. A. (1955). Relations between pigment content and photosynthetic characteristics in a blue-green algae. J. gen. Physiol. 39, 11.

Provasoli, L., Mclaughuin, J. J. A. \& Droop, M. R. (1957). The development of artificial media for marine algae. Arch. Mikrobiol. 25, 392.

Shibata, K. (1958). Spectrophotometry of intact biological materials. J. Biochem. 45, 599.

Spoenr, H. A. \& Mrlner, H. W. (1949). The chemical composition of Chlorella; effect of environmental conditions. Plant Physiol. 24, 120.

van BaAlen, C. (1962). Studies on marine blue-green algae. Bot. Marina, 4, 129. 